\title{
ABBREVIATIONS USED IN THE TEXT
}

AFCS American Federation of Catholic Societies

AFL American Federation of Labor

$\mathrm{AOH} \quad$ Ancient Order of Hibernians

APA American Protective Association

CPI Committee on Public Information

CTAU Catholic Total Abstinence Union

ERA Equal Rights Association

IWW Industrial Workers of the World

KOC Knights of Columbus

NCCM National Council of Catholic Men

NCCW National Council of Catholic Women

NCWC National Catholic Welfare Conference

NWLB National War Labor Board

PCFU Providence Central Federated Union

RICLU Rhode Island Central Labor Union

RILWV Rhode Island League of Women Voters

RISA Rhode Island Suffrage Association

RISFL Rhode Island State Federation of Labor

RISFWC Rhode Island State Federation of Women's Clubs

RIWSA Rhode Island Woman Suffrage Association

SLP Socialist Labor Party

USJB Union Saint-Jean-Baptiste

UTW United Textile Workers 

BALLOTS AND BIBLES 
